\title{
Severe digital ischemia due to systemic sclerosis successfully treated with bosentan: case report
}

\author{
Tratamento de isquemia digital severa em paciente com esclerose \\ sistêmica utilizando bosentana: relato de caso
}

\author{
Cesar José Guimarães Soares ${ }^{1}$, Boris A. Cruz $^{2}$
}

\begin{abstract}
Systemic sclerosis (SSc) is an autoimmune connective tissue disease characterized by cutaneous and visceral fibrosis and widespread vascular pathology. Raynaud's phenomenon is one of the most common manifestations of SSc. It may lead to complications such as digital ulceration and infarction and its treatment remains elusive. We present the case of a female patient with severe digital ischemia secondary to SSc. Treatment using vasodilators and prostacyclin analogues was ineffective, but the patient experienced a remarkable response to bosentan, a dual endothelin receptor antagonist. This report suggests that endothelin antagonists may benefit patients with $\mathrm{SSc}$ and vasculopathy as a major feature of the disease, including limb ischemia.
\end{abstract}

Keywords: Systemic sclerosis, digital ischemia, bosentan.

\section{Introduction}

Systemic sclerosis (SSc) is an autoimmune connective tissue disease characterized by cutaneous and visceral fibrosis and widespread vascular pathology. ${ }^{1}$ Raynaud's phenomenon is one of the most common manifestations of SSc and it is present in more than $85 \%$ of patients. It usually appears simultaneously with other symptoms, but it may antedate them by several years. Typically, excessive vasoconstrictive response leads to pallor and cyanosis of distal extremities, particularly the digits, with complications including digital ulceration and infarction. ${ }^{1,2}$

Although treatment with a variety of vasodilators, such as calcium channel blockers, angiotensin-converting enzyme inhibitors and alpha-adrenergic inhibitors, has been shown to be effective in treating Raynaud's phenomenon, digital ischemia remains a serious complication for many patients, and effective therapy remains

\section{Resumo}

Esclerose sistêmica (SSc) é uma doença auto-imune do tecido conjuntivo caracterizada por fibrose cutânea e visceral, além de vasculopatia difusa. O fenômeno de Raynaud é uma das manifestações mais comuns da SSc, que pode levar a complicações como úlceras digitais e infarto. Seu tratamento ainda é indefinido. Apresentamos o caso de uma paciente com isquemia digital grave secundária a SSc. O tratamento incluindo vasodilatadores e análogos de prostaciclina foi ineficaz, mas a paciente apresentou excelente resposta ao bosentan, um antagonista de receptores de endotelina. Este relato sugere que antagonistas de endotelina podem beneficiar pacientes com SSc e vasculopatia como principal característica da doença, incluindo isquemia de extremidades.

Palavras-chave: Esclerose sistêmica, isquemia digital, bosentan.

elusive. ${ }^{3}$ We present the case of a patient with severe digital ischemia secondary to $\mathrm{SSc}$ who experienced a remarkable response to bosentan, a dual endothelin receptor antagonist.

\section{Case report}

A 44-year old female patient was submitted to a medical evaluation due to painful digital ulcers. She described a 24-month history of Raynaud's phenomenon and lately ischemic ulcers developed in several fingertips. She described dysphagia but no other musculoskeletal, gastrointestinal or respiratory symptoms were reported.

On examination, she was found to have ischemic ulcers in several fingertips and cutaneous thickening affecting her digits, dorsum of both hands and arms (below the elbows), consistent with skin fibrosis due to

1. MD. Clínica de Angiologia e Cirurgia Vascular, Belo Horizonte, MG, Brazil. Member, Minas Gerais Vasculitis Study Group.

2. MD. Rheumatology Department, Biocor Instituto, Nova Lima, MG, Brazil. Member, Minas Gerais Vasculitis Study Group.

Manuscript received Mar 12, 2007, accepted for publication June 14, 2007. 


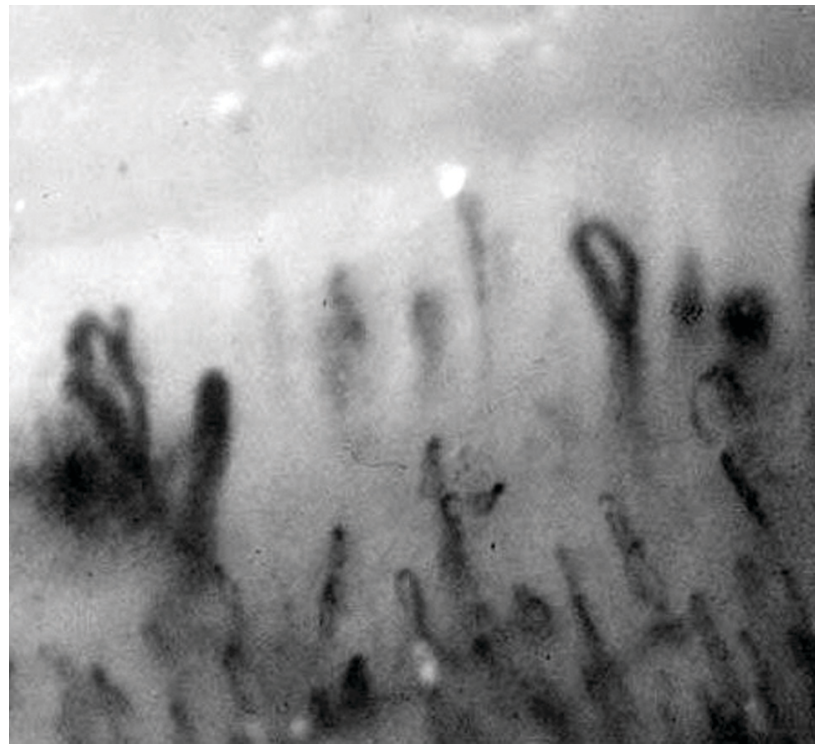

Figure 1 - Detail of the nailfold capillaroscopy showing the so called "scleroderma pattern," characterized by irregularly enlarged loops (giant capillaries) and loop dropout areas, typical of systemic sclerosis

SSc. She presented a positive antinuclear antibody (Hep-2) ratio of 1:5120 - centromeric pattern - and the nailfold capillaroscopy showed the so-called "scleroderma pattern," characterized by irregularly enlarged loops (giant capillaries) and loop dropout areas, typical of SSc (Figure 1). Therefore, diagnosis of SSc in its limited cutaneous form was confirmed. ${ }^{4}$ Screening for antiphospholipid antibodies was negative in at least three different occasions. ${ }^{1}$

Treatment including wound care, calcium channel blockers and aspirin was ineffective. Alprostadil - a prostacyclin analogue - and sildenafil were used, but the ischemic necrosis progressed (Figure 2). The patient complained of excruciating pain, requiring strong analgesics, and she was severely disabled. ${ }^{2}$

Bosentan - an oral endothelin dual receptor antagonist - was prescribed initially in the dose of $62.5 \mathrm{mg}$ twice a day for 2 weeks and then $125 \mathrm{mg}$ twice a day. Pain promptly improved as the frequency of cyanosis episodes in her fingers decreased. After 8 weeks, all signs of ischemia had disappeared. Nevertheless, the distal phalange of the third right finger needed to be surgically removed (Figure 3). After 6 months of follow-up, skin

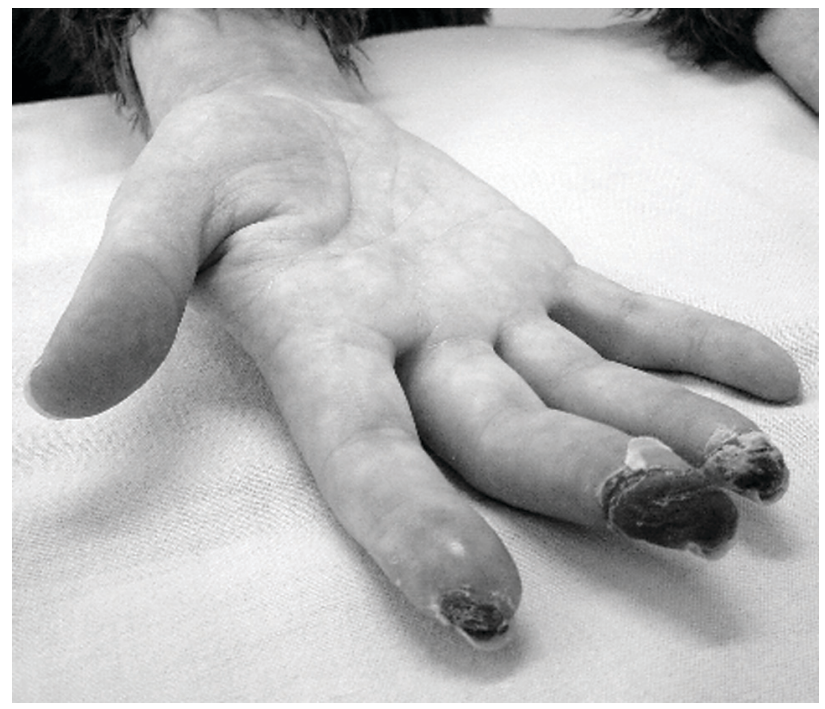

Figure 2 - Picture of the patient's right hand with diffuse edema, cyanosis of extremities and ischemic necrosis of the second, third and fourth digits. At this time, the patient had already received wound care, calcium channel blockers, prostacyclin analogues and sildenafil, but ischemic changes progressed

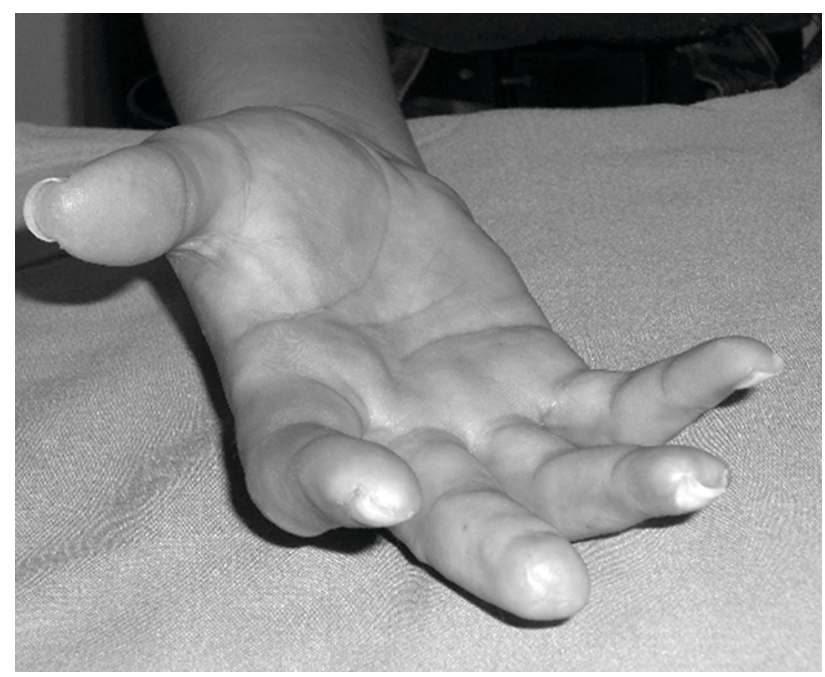

Figure 3 - Eight weeks after initiation of bosentan all ischemic changes disappeared. Nevertheless, the distal phalange of the third digit needed to be surgically removed

fibrosis in her arms and hands remains stable and she is asymptomatic under bosentan and omeprazole. ${ }^{3}$ 


\section{Discussion}

Pathological changes in SSc encompass a spectrum reflecting variable stages of development and progression of three major processes in the affected tissues: 1) severe tissue fibrosis with exaggerated deposition of collagen and other connective tissue components in the extracellular matrix; 2) chronic inflammation, occurring predominantly in the early stages of disease and characterized by infiltration with mononuclear cells, mostly of the macrophage and T-cell lineages; and 3) microvascular disease, characterized by intimal proliferation, concentric subendothelial deposition of collagen and mucinous material, and narrowing and thrombosis of the vessel lumen. ${ }^{5}$

The underlying physiologic basis for the diffuse vasculopathy in SSc is unknown. ${ }^{6}$ Initial events are thought to involve endothelial cell injury, with subsequent loss of normal vasodilatory mediators including prostacyclin and nitric oxide. As a result, abnormal responses to vasoconstrictive mediators, including catecholamines, may occur. ${ }^{7}$ Endothelial injury also leads to increased release of endothelin 1 (ET-1), which is a 21-amino acid peptide released by endothelial cells that has a potent vasoconstrictive effect. It binds to two cognate receptors, ET-A and ET-B, which are variably expressed on endothelial cells, smooth muscle cells, fibroblasts and other cells throughout the body. ${ }^{8}$ ET-1 is found in increased levels in the serum of patients with SSc, suggesting that it plays a role in the pathogenesis of SSc vascular disease. ${ }^{9}$ Bosentan, an oral endothelin dual receptor antagonist, was recently shown to be effective in the treatment of pulmonary hypertension in the setting of SSc. ${ }^{10,11}$ Like Raynaud's phenomenon, pulmonary hypertension in these patients is characterized by both functional and structural abnormalities, and the structural lesion in pulmonary hypertension resembles the vascular lesion in SSc-associated Raynaud's.

Others have already suggested the benefit of bosen$\tan$ in the treatment of digital ulcers secondary to SSc. Two randomized controlled trials have shown a positive effect in preventing new ulcers and improving hand function, but both studies failed to confirm an improvement in healing previous active ulcers. ${ }^{12,13}$ It is unclear why a drug that presumably promotes vasodilatation as an antagonist of ET-1 would not also promote ulcer healing. The authors hypothesized that the ulcers that were present at the time of study entry were chronic, and that other factors, including infection, lack of underlying granulation tissue, and poor epithelial function, masked any salutary effects of bosentan on blood flow. In addition, one could not exclude limitation of those trials, including selection and measurement biases. In our patient, introduction of bosentan dramatically changed the course of the disease. We understand that there is a subset of patients with predominance of vasculopathy as feature of the disease, clinically expressed as pulmonary hypertension and/or ischemia of extremities. Those patients may benefit the most of vasodilators such as endothelin antagonists.

In summary, we presented the case of a patient with severe digital ischemia secondary to SSc that experienced a remarkable response to bosentan, an oral dual endothelin receptor antagonist. This report suggests that endothelin antagonists may benefit patients with SSc and vasculopathy as a major feature of the disease, including limb ischemia.

\section{References}

1. Korn JH. Pathogenesis of systemic sclerosis. In: Koopman WJ, editor. Arthritis and allied conditions. Baltimore: Williams \& Wilkins; 2001. p. 1643-54.

2. Block JA, Sequeira W. Raynaud's phenomenon. Lancet. 2001;357:2042-8.

3. Desai R, Korn JH. Diagnosis and management of Raynaud phenomenon. J Musculoskel Med. 2003;20:124-35.

4. LeRoy EC, Black C, Fleischmajer R, et al. Scleroderma (systemic sclerosis): classification, subsets and pathogenesis. J Rheumatol. 1988;15:202-5.

5. Jimebez AS, Derk CT. Following the molecular pathways toward an understanding of the pathogenesis of systemic sclerosis. Ann Intern Med. 2004;140:37-50.

6. Campbell PM, LeRoy EC. Pathogenesis of systemic sclerosis: a vascular hypothesis. Semin Arthritis Rheum. 1975;4:351-68.

7. Gryglewski RJ, Botting RM, Vane JR. Mediators produced by the endothelial cell. Hypertension. 1988;12:530-48.

8. Inoue A, Yanagisawa M, Kimura S, et al. The human endothelin family: three structurally and pharmacologically distinct isopeptides predicted by three separate genes. Proc Natl Acad Sci USA. 1989;86:2863-7.

9. Biondi ML, Marasini B, Bassani C, Agostoni A. Increased plasma endothelin levels in patients with Raynaud's phenomenon. N Engl J Med. 1991;324:1139-40. 
10. Rubin LJ, Badesch DB, Barst RJ, et al. Bosentan therapy for pulmonary arterial hypertension. $\mathrm{N}$ Engl $\mathrm{J}$ Med. 2002;346:896-903.

11. Sitbon O, Badesch DB, Channick RN, et al. Effects of the dual endothelin receptor antagonist bosentan in patients with pulmonary arterial hypertension: a 1-year follow-up study. Chest. 2003;124:247-54.

12. Korn JH, Mayes M, Matucci Cerinic M, et al. Digital ulcers in systemic sclerosis: Prevention by treatment with bosentan, an oral endothelin receptor antagonist. Arthritis Rheum. 2004;50:3985-93
13. Seibold JR, Matucci-Cerinic M, Denton CP, et al. Bosentan reduces the number of new digital ulcers in patients with systemic sclerosis. Ann Rheum Dis. 2006;65(Suppl II):S90.

Correspondence:

Cesar José Guimarães Soares

Rua Padre Marinho, 49/903, Santa Efigênia

CEP 30140-040 - Belo Horizonte, MG

Fax: Fax: (31) 3241.4129

E-mail: cesarguimaraess@oi.com.br 